\title{
$\mathrm{Al} 5083$ 합금 용접부의 기계적 물성에 미치는 $\mathrm{Mg}$ 의 영향
}

\section{김동윤·김동철·강문진·김영민* \\ 한국생산기술연구원 용접접합그룹 \\ Effect of Aluminum Welding Wire Mg Content on the Mechanical Properties of Al 5083 Alloy Weld Metal}

\author{
Dongyoon Kim, Dongcheol Kim, Munjin Kang, and Young-Min Kim* \\ Joining R\&D Group, Korea Institute of Industrial Technology, Incheon 21999, Republic of Korea
}

\begin{abstract}
A new aluminum welding wire with $0.8 \mathrm{wt} \%$ higher in $\mathrm{Mg}$ content was developed and compared with commercial welding wire of the 5000 series. The weldability of the Al5083 base material was evaluated using high current metal inert gas (MIG) welding, using the developed Al5183 and commercial Al5183 welding wire. For the wire with $5.1 \mathrm{wt} \% \mathrm{Mg}$ content, the hardness of the weld metal decreased with increasing heat input to the center of the weld under low and high heat input conditions. For the wire with $5.9 \mathrm{wt} \% \mathrm{Mg}$ content, the hardness of the weld metal did not decrease under low and high heat input conditions. The wire with $5.1 \mathrm{wt} \% \mathrm{Mg}$ content exhibited a tensile strength of about $300 \mathrm{MPa}$ under the low/medium heat input conditions. The tensile strength decreased to $284 \mathrm{MPa}$ under high heat input conditions. However, the welding wire with $5.9 \mathrm{wt} \% \mathrm{Mg}$ content exhibited a tensile strength of $300 \mathrm{MPa}$ regardless of the heat input condition. Dendritic microstructures were observed in the center of the welds in both wires, with $\mathrm{Mg}$ contents of $5.1 \mathrm{wt} \%$ and $5.9 \mathrm{wt} \%$, and the second dendrite arm spacing (SDAS) increased with increasing heat input.
\end{abstract}

(Received May 8, 2017; Accepted July 10, 2017)

Keywords: aluminum 5083 alloy, magnesium, welding wire, metal inert gas welding, tensile strength, hardness

\section{1. 서 론}

세계적인 에너지 수요증가 및 석유 자원 고갈로 인해 높은 연료 효율과 낮은 탄소 배출 특성을 가지고 있는 액화천연가 스(Liquified Natural Gas, LNG)의 수요가 지속적으로 증가 하고 있는 상황이다 [1-4]. 이에 따라 $\mathrm{LNG}$ 를 저장하는 저장 고의 수요도 증가하는 추세이다. $\mathrm{LNG}$ 저장고는 $\mathrm{LNG}$ 를 액화 천연가스로 액화시켜 저장해야 하기 때문에 저장고의 소재 는 액체의 압력 및 극저온 특성을 만족해야만 한다. 이러한 LNG 저장고로 쓰이는 소재는 스테인리스강, 알루미늄 합금, 니켈 합금강 등이 있다. 이 중 알루미늄 5000계열 합금은 비 열처리형 합금으로 강도가 우수하며 극저온(-196 $\left.{ }^{\circ} \mathrm{C}\right)$ 에서 우 수한 기계적 특성으로 인해 $\mathrm{LNG}$ 탱크 소재로 적용되고 있다 [5-8]. LNG 탱크 소재로 적용 가능한 알루미늄 합금 소재는

*Corresponding Author: Young-Min Kim [Tel: +82-32-850-0232, E-mail: ymkim77@kitech.re.kr] Copyright (c) The Korean Institute of Metals and Materials
5000 계열의 5052, 5083 소재 등이 있는데 높은 용접 아크열 에 의해 비교적 강도저하가 작은 5083 소재가 주로 적용되고 있다. 알루미늄 5083 합금은 마그네슘 함량이 4-5 wt\%로 다 른 알루미늄 합금에 비해 높은 강도와 내식성 및 용접성을 가 진다 [9-11]. 알루미늄 5000계열 합금은 $\mathrm{Mg}$ 의 첨가에 의한 고용강화를 통해 강도를 증가시키지만, 5000계열 알루미늄 합금내의 $\mathrm{Mg}$ 성분은 산화 및 발화 특성으로 인하여 첨가할 수 있는 마그네슘 함량이 제한되어 있다.

알루미늄 5083 합금을 모재로 이용한 아크 용접에서는 요 구 용착량을 만족하기 위해 가공 후 다층 용접을 실시하게 되 는데, 이 때 용접부 균열 및 기공과 같은 용접 결함이 발생하 기 쉽다. 이러한 용접결함 방지를 위해서 대전류 용접기술을 통한 용접 횟수를 줄이는 방법 등이 있다. 또한 알루미늄 5000 계열 합금의 아크 용접시 용착금속부 연화로 인한 용접 부 강도저하 문제도 있다. 예로 LNG 탱크 소재로 사용되고 있는 5083 알루미늄 소재에 대한 용접부 요구강도는 현재 최 
Table 1. The chmeical composition and mechanical properties of base material Al5083

\begin{tabular}{c|c|c|c|c|c|c|c|c|c}
\hline $\mathrm{Al} 5083$ & $\mathrm{Si}$ & $\mathrm{Fe}$ & $\mathrm{Cu}$ & $\mathrm{Mn}$ & $\mathrm{Mg}$ & $\mathrm{Cr}$ & $\mathrm{Zn}$ & $\mathrm{Ti}$ & $\mathrm{Al}$ \\
\hline $\mathrm{wt} \%$ & 0.205 & 0.258 & 0.035 & 0.687 & 4.496 & 0.105 & 0.039 & 0.0275 & $\mathrm{Bal}$. \\
\hline \multicolumn{3}{c|}{ Yield strength (MPa) } & \multicolumn{3}{c|}{$\begin{array}{c}\text { Tensile strength } \\
(\mathrm{MPa})\end{array}$} & \multicolumn{3}{|c}{ Elongation (\%) } \\
\hline \multicolumn{3}{c|}{215} & \multicolumn{3}{c|}{322} & \multicolumn{3}{c}{18.2} \\
\hline
\end{tabular}

Table 2. The chemical composition and mechanical properties of filler wire

\begin{tabular}{c|c|c|c|c|c|c|c|c|c}
\hline & $\mathrm{Si}$ & $\mathrm{Fe}$ & $\mathrm{Cu}$ & $\mathrm{Mn}$ & $\mathrm{Mg}$ & $\mathrm{Cr}$ & $\mathrm{Ca}$ & $\mathrm{Ti}$ & $\mathrm{Al}$ \\
\hline wire-1 & 0.07 & 0.17 & - & 0.66 & 5.10 & 0.07 & - & 0.07 & Bal. \\
\hline wire-2 & 0.06 & 0.10 & 0.01 & 0.66 & 5.98 & 0.10 & 0.04 & 0.04 & Bal. \\
\hline
\end{tabular}

소 $270 \mathrm{MPa}$ 를 요구하고 있는 상황이다. $\mathrm{LNG}$ 탱크 소재로 적 용되고 있는 알루미늄 소재 두께는 $25 \mathrm{~mm}$ 에서 최대 $80 \mathrm{~mm}$ 로 아크 용접시 적용되는 입열이 상대적으로 높아 비점이 낮 은 $\mathrm{Mg}$ 의 기화가 발생할 수 있으며, 이로 인해 용착금속부의 연화가 발생하여 선급에서 요구하는 강도를 확보하지 못할 경우가 발생할 가능성이 있다 [12-14]. 이러한 문제를 해결하 기 위해서는 아크 용접시 사용되는 용접와이어에 $\mathrm{Mg}$ 의 함 량을 증가시켜 용착금속부 연화를 방지하는 방법이 있다 [15].

최근 알루미늄 5083 합금의 대전류 아크 용접을 위해 기존 상용 용접와이어 대비 $\mathrm{Mg}$ 함량을 증가시킨 새로운 알루미늄 합금용 용접와이어가 개발되었다. 본 연구에서는 기존 5083 알루미늄 합금용 용접와이어와 새롭게 개발된 알루미늄 5083 합금용 용접와이어를 이용하여 $\mathrm{Mg}$ 함량이 알루미늄 5083 합금 용접부의 기계적 특성에 미치는 영향에 대해서 연 구하였다. 본 연구를 위해서 직경 $4.8 \mathrm{~mm}$ 용접와이어를 이용 하여 두께 $25 \mathrm{~mm}$ 의 알루미늄 5083 합금 모재를 양면 용접하 였다. 그 후 용접부의 경도, 인장 강도 등의 기계적 물성을 평 가하였으며 $\mathrm{Mg}$ 함량에 따른 용접부의 변화를 관찰 및 비교

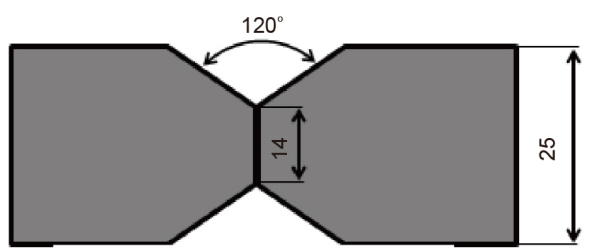

Fig. 1. The schematic diagram of welding sample. The groove angle is $120^{\circ}$ and the root face is $14 \mathrm{~mm}$.

하기 위해 미세조직 분석 및 화학성분을 분석하였다.

\section{2. 실험방법}

본 연구에서는 정 전류형의 $1500 \mathrm{~A}$ 급 metal inert gas (MIG) 용접기를 사용하였으며, 용접 토치는 보호가스의 편 류, 난류를 줄이고 용접 중 용융부를 외부 공기로부터 완전하 게 차단하기 위하여 대구경 이중 보호가스 공급용 토치를 사 용하였다. 실험에 사용된 모재는 두께 $25 \mathrm{~mm}$ 의 5083 알루미 늄 합금을 사용하였으며 모재의 기계적 특성 및 화학조성은 표 1 과 같다. 용접와이어로는 $\mathrm{Mg}$ 함량이 $5.1 \mathrm{wt} \%$ 인 $\mathrm{Al} 5183$ 상용 와이어 및 $\mathrm{Al} 5183$ 보다 $\mathrm{Mg}$ 함량이 $0.9 \mathrm{wt} \%$ 정도 더 들 어있는 새롭게 개발된 용접와이어 2가지를 사용하였으며 용 접와이어의 성분은 표 2에 나타내었다.

양면 완전용입의 용접부 확보 및 최적 용접조건 선정을 위 해 BOP 용접을 통하여 그림 1과 같이 X-groove를 선정하였 으며, 표 3은 본 연구에서 사용한 용접조건을 보여주고 있다. 용접전류 $600 \mathrm{~A}$, 전압 $32 \mathrm{~V}$, 용접속도 $50 \mathrm{~cm} / \mathrm{min}$ 으로 전면 first pass 용접조건 선정하였으며 후면 second pass 는 입열량 에 따라 용접을 수행한 후 용입 특성을 비교하였다. 용접와이 어 종류에 따른 용접부의 기계적 특성을 평가하기 위해 용접 부 경도 및 인장강도를 측정하였다. 인장시험편의 경우 노치 효과를 최소화하기 위해 상면에서 $3 \mathrm{~mm}$, 하면에서 $2 \mathrm{~mm}$ 밀

Table 3. The welding conditions used in the study

\begin{tabular}{|c|c|c|c|c|c|c|c|c|}
\hline & & & $\begin{array}{l}\text { welding current } \\
\text { (A) }\end{array}$ & $\begin{array}{c}\text { welding voltage } \\
\text { (V) }\end{array}$ & $\begin{array}{c}\text { welding speed } \\
(\mathrm{cm} / \mathrm{min})\end{array}$ & $\begin{array}{c}\text { heat input } \\
(\mathrm{kJ} / \mathrm{cm})\end{array}$ & shielding gas & CTWD \\
\hline \multirow{4}{*}{ wire-1 } & \multicolumn{2}{|c|}{ first pass } & 600 & 32 & 50 & 23 & \multirow{4}{*}{$\begin{array}{c}\text { Ar } 50 \% \\
+ \text { He } 50 \%\end{array}$} & \multirow{4}{*}{$45 \mathrm{~mm}$} \\
\hline & \multirow{3}{*}{ second pass } & A & 651 & 33.4 & 40 & 32.6 & & \\
\hline & & B & 607 & 32.2 & 30 & 39.1 & & \\
\hline & & $\mathrm{C}$ & 680 & 34.5 & 30 & 46.9 & & \\
\hline \multirow{4}{*}{ wire-2 } & \multicolumn{2}{|c|}{ first pass } & 600 & 32 & 50 & 23 & \multirow{4}{*}{$\begin{array}{c}\text { Ar } 50 \% \\
+ \text { He } 50 \%\end{array}$} & \multirow{4}{*}{$45 \mathrm{~mm}$} \\
\hline & \multirow{3}{*}{ second pass } & A & 651 & 32.4 & 40 & 31.6 & & \\
\hline & & B & 608 & 31.2 & 30 & 37.9 & & \\
\hline & & $\mathrm{C}$ & 652 & 33.8 & 30 & 44.1 & & \\
\hline
\end{tabular}


(a)

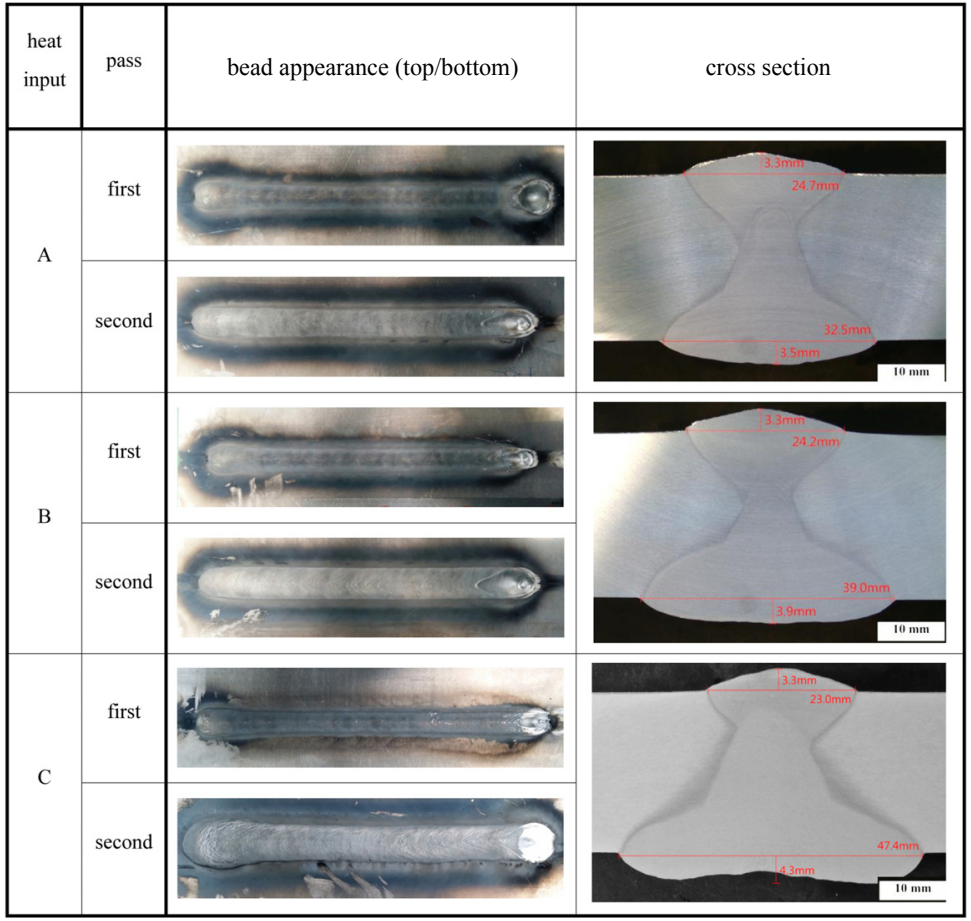

(b)

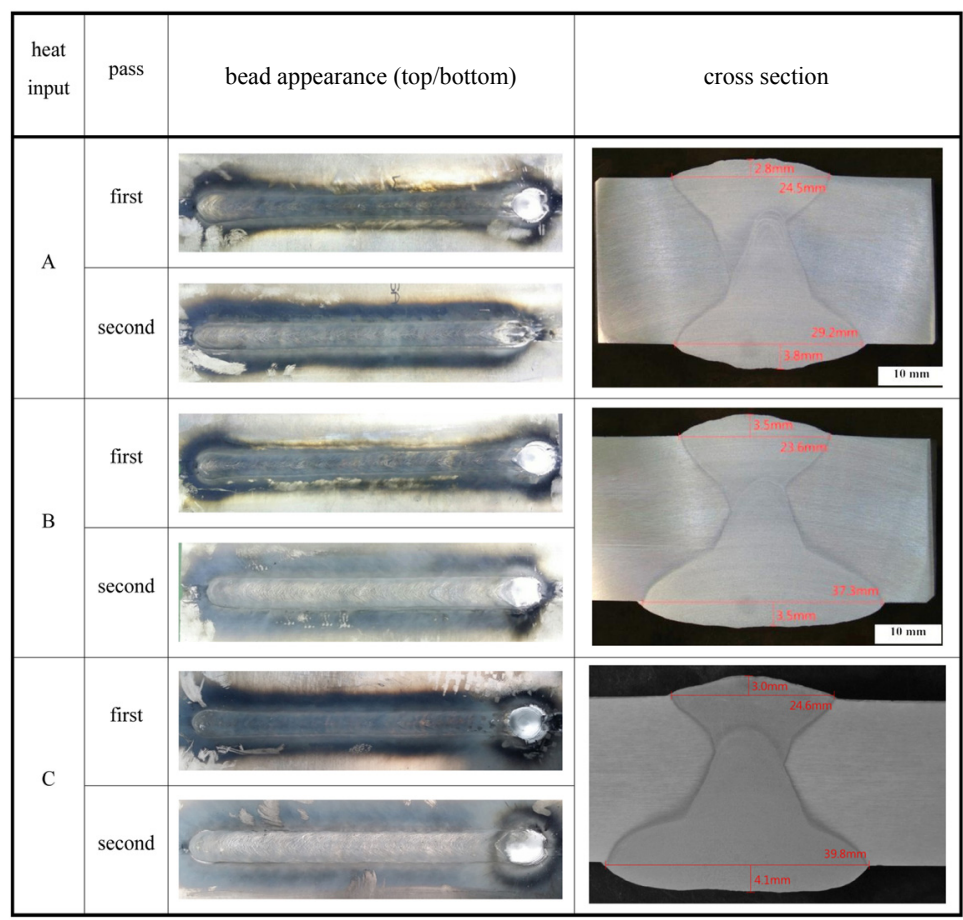

Fig. 2. Bead shape and optical micrographs of cross section welded using (a) wire-1 and (b) wire-2

링 가공하였다. 인장시편의 gauge length는 $75 \mathrm{~mm}$ 이며, 2개 의 인장시편을 가공하여 인장시험을 실시한 후 인장강도를 평균값으로 확보했다. 용접부의 단면은 광학현미경(Optical Microscope, $\mathrm{OM})$ 을 통해 관찰하였으며 미세조직은 전자주
사현미경 (Scanning Electron Microscope, SEM)을 이용하여 분석하였으며, 용접 와이어 종류에 따른 용접부의 $\mathrm{Mg}$ 함량 변화를 알아보기 위해 Energy Dispersive X-ray Spectrometer (EDS) 분석을 실시하였다. 
(a)

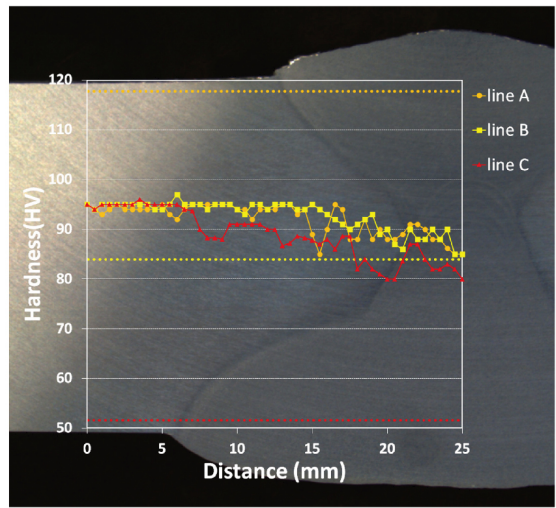

(b)

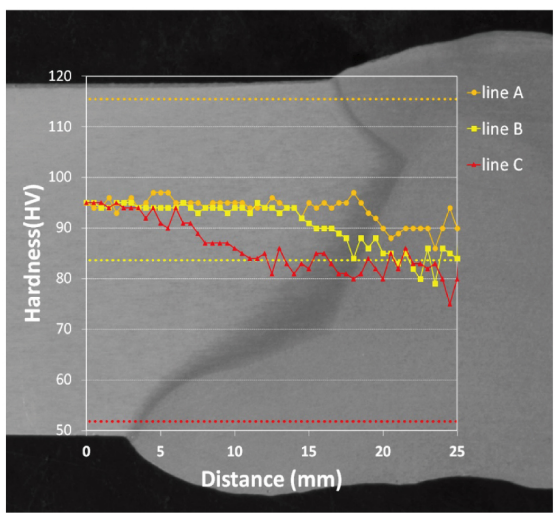

Fig. 3. Hardness profile using wire-1 with respect to the heat input condition: (a) heat input condition $\mathrm{A}$ and (b) heat input condition $\mathrm{C}$

\section{3. 결과 및 고찰}

\section{1 용접 비드}

저입열, 중입열, 고입열 조건으로 수행한 용접 결과에 대한 비드외관 및 용접단면형상을 그림 2에 나타내었다. Wire-1을 사용한 경우 용접 비드외관을 살펴 본 결과 3 가지 조건 모두 언더컷과 같은 용접결함은 없었다(그림 2(a)). 용접 단면시험 결과 second pass의 입열량이 증가할수록 비드 폭이 증가하 고 second pass로 인해 용입이 증가하였으며 이를 통해 3 가 지 입열조건에서 모두 건전한 용접부를 형성하는 것을 확인 하였다. 그림 2(b)와 같이 $\mathrm{Mg}$ 함량이 $5.9 \mathrm{wt} \%$ 인 wire-2를 사 용했을 경우에도 wire-1을 사용했을 때와 마찬가지로 언더컷 과 같은 용접결함 없이 건전한 용접부를 보여주고 있다.

\section{2 용접부 경도}

Second pass 의 저입열 조건과 고입열 조건에 대한 용접부 경도를 측정하였다. 모재의 상면(first pass)에서 $1 \mathrm{~mm}$ 아래 에서 모재에서 용착금속부 중심까지 $25 \mathrm{~mm}$ 에 대하여 0.5 (a)

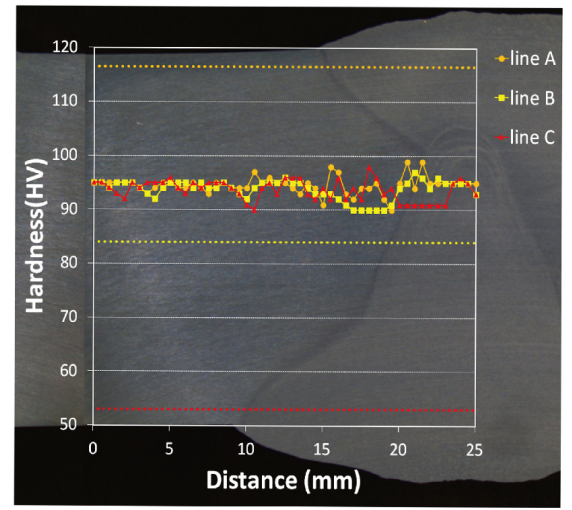

(b)

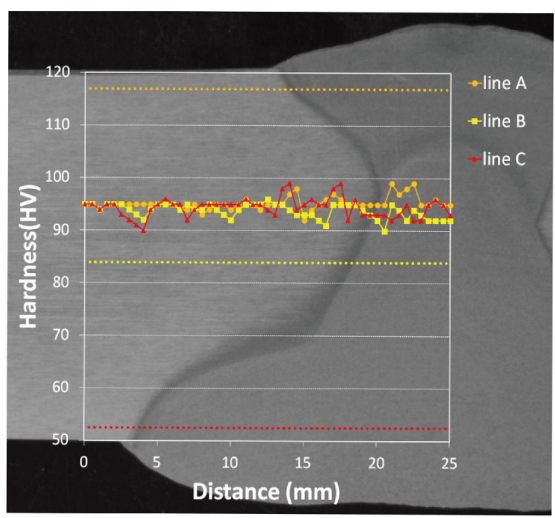

Fig. 4. Hardness profile using wire-2 with respect to the heat input condition: (a) heat input condition $\mathrm{A}$ and (b) heat input condition $\mathrm{C}$

Table 4. Tensile strength and elongation of the welds using wire-1 and wire-2

\begin{tabular}{c|c|c|c}
\hline \multirow{2}{*}{ wire-1 } & $\begin{array}{c}\text { heat input } \\
\text { condition }\end{array}$ & $\begin{array}{c}\text { Tensile strength } \\
(\mathrm{MPa})\end{array}$ & Elongation (\%) \\
\cline { 2 - 4 } & $\mathrm{A}$ & 300.5 & 16.5 \\
\cline { 2 - 4 } & $\mathrm{B}$ & 302 & 18.5 \\
\hline \multirow{3}{*}{ wire-2 } & $\mathrm{C}$ & 284 & 14.5 \\
\cline { 2 - 4 } & $\mathrm{A}$ & 302 & 20 \\
\cline { 2 - 4 } & $\mathrm{B}$ & 302 & 17.5 \\
\hline
\end{tabular}

$\mathrm{mm}$ 간격으로 경도를 측정하였다(line A). Line B 는 모재의 상면과 하면의 중간부분에서 측정을 하였으며, line C 는 모 재의 하면(second pass)쪽에서 경도 측정을 실시하였다. 경도 는 HV 0.2 로 측정하였으며, line 당 50 포인트를 측정하였다.

그림 3과 4는 wire-1 및 wire-2를 이용한 저입열과 고입열 용접부의 경도를 측정한 결과이다. 모재의 경도는 약 $95 \mathrm{HV}$ 이며, 모든 line에서 용착금속부의 경도는 모재의 경도보다 낮게 나타난다. 용착금속부 중심으로 이동할수록 경도는 감 소하며 고입열의 경우 저입열보다 용착금속부 중심으로 갈 


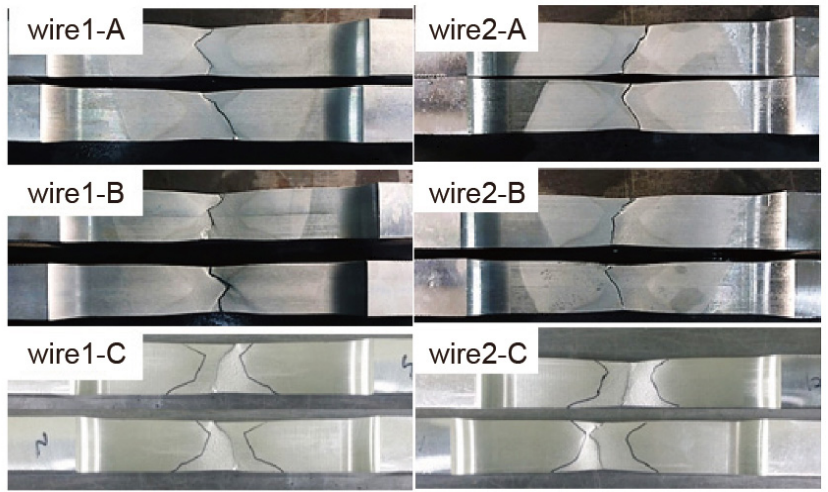

Fig. 5. weld sample after tensile test using wire-1 and wire- 2 with respect to the heat input condition

(a)
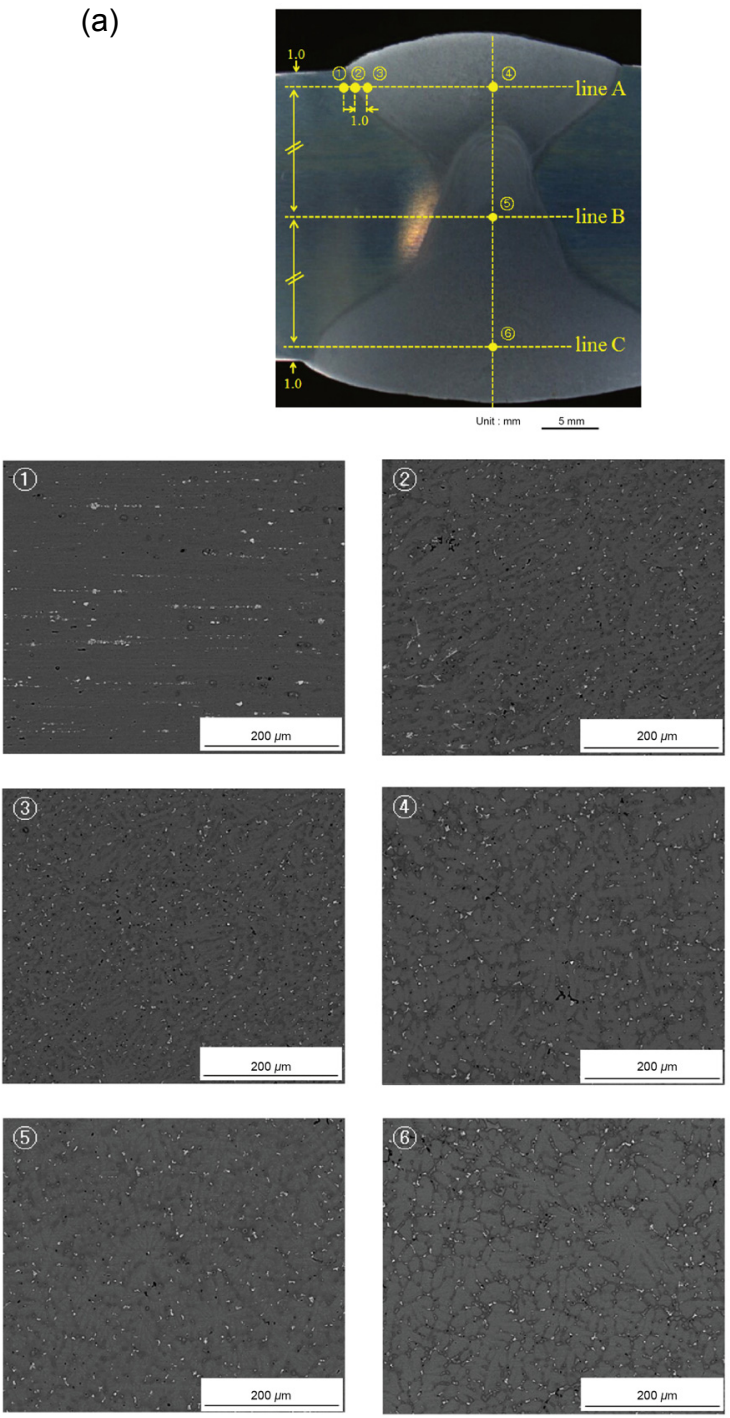

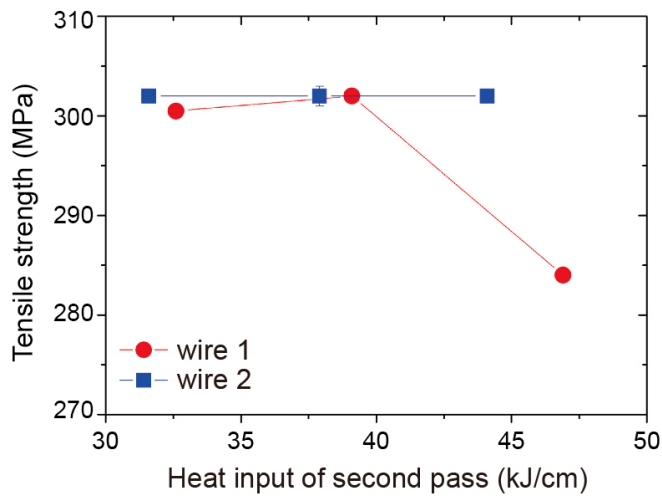

Fig. 6. Tensile strength with respect to heat input of second pass

(b)

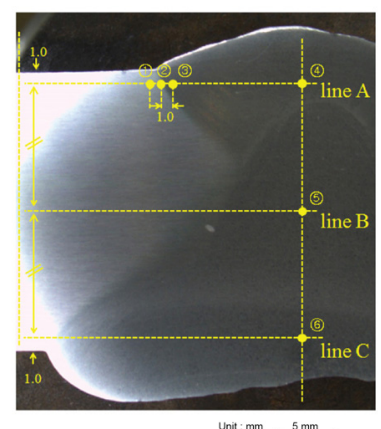

Unt: $\mathrm{mm} \stackrel{5 \mathrm{~mm}}{-}$
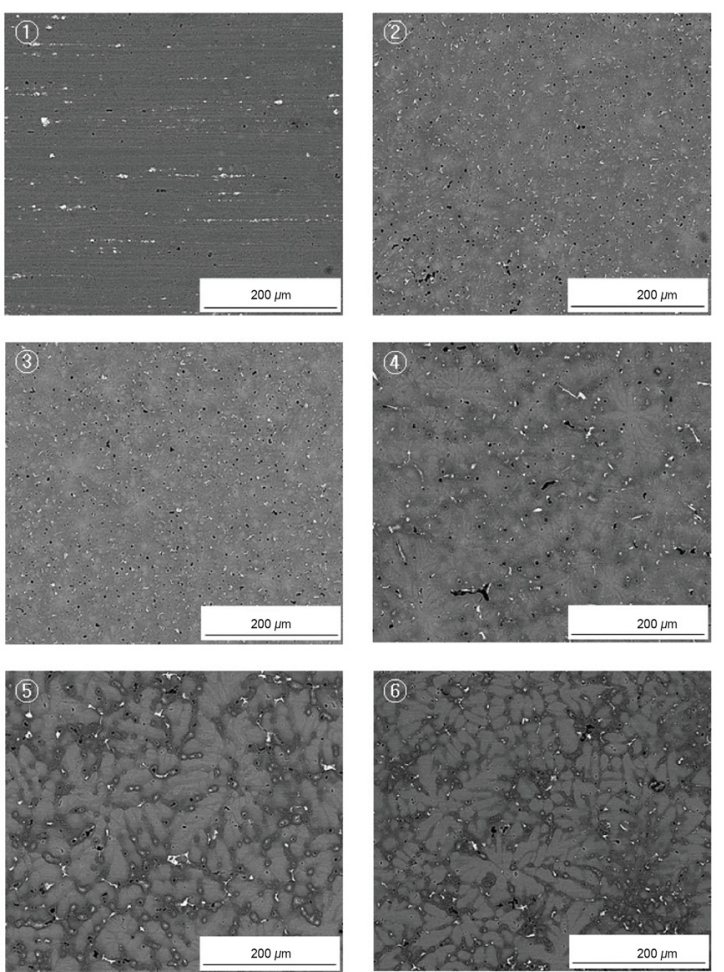

Fig. 7. Microstructure of base material, heat affected zone and fusion zone using wire-1 with respect to (a) heat input condition A (b) heat input condition $\mathrm{C}$ 
(a)
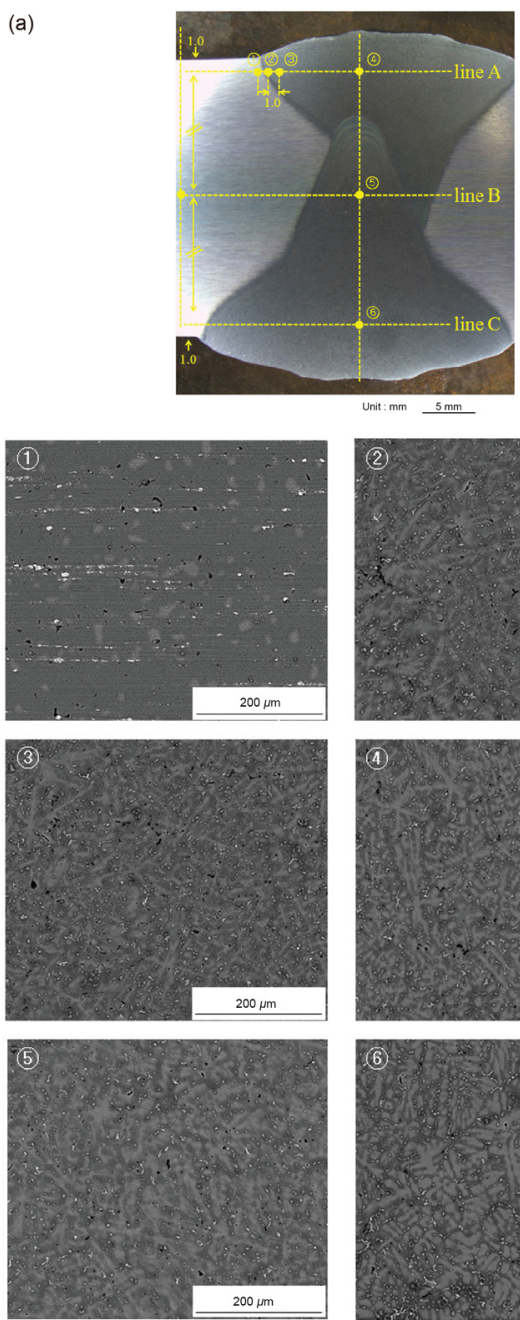
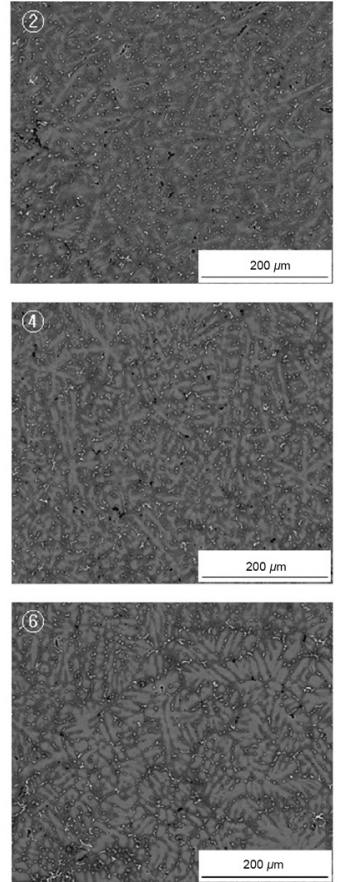

(b)
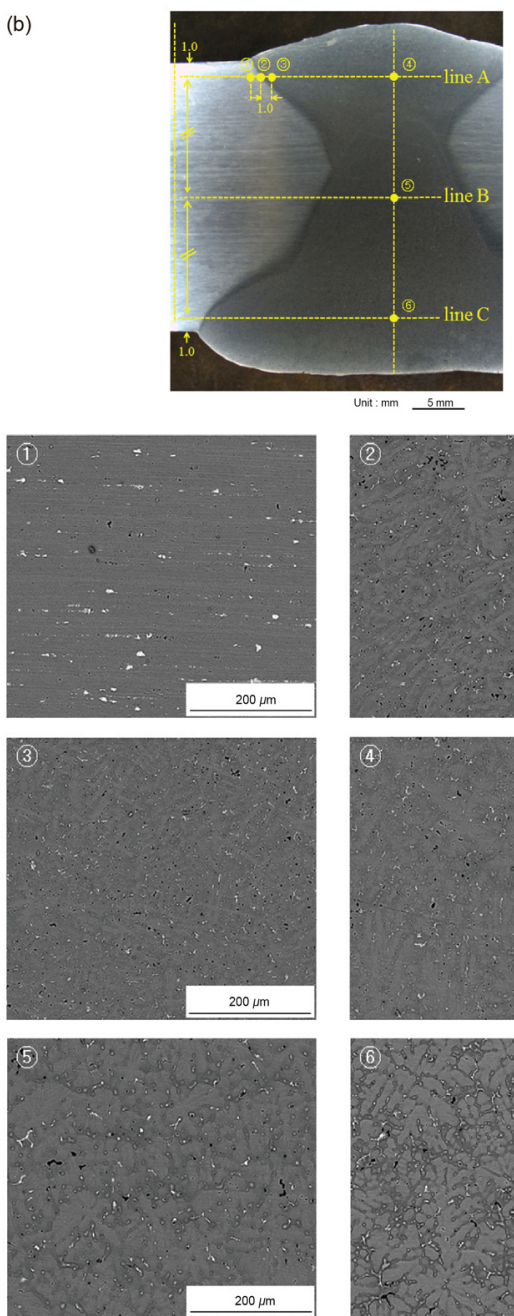
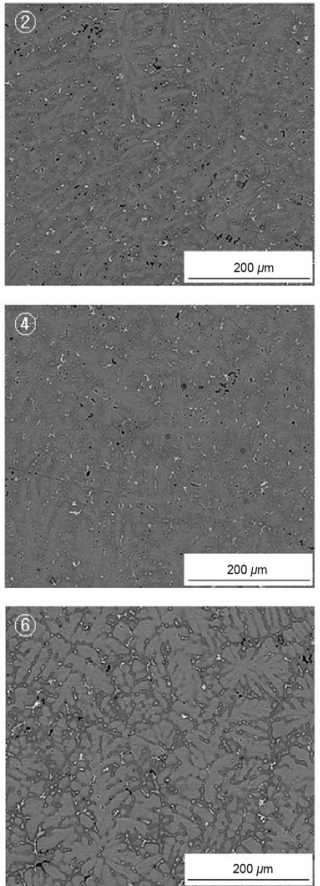

Fig. 8. Microstructure of base material, heat affected zone and fusion zone using wire-2 with respect to (a) heat input condition A (b) heat input condition $\mathrm{C}$

수록 경도의 감소폭이 커지며 용접부 중심에서의 경도는 line $\mathrm{C}$ 에서 최저 $75 \mathrm{HV}$ 값을 나타내었다. Wire-2의 경우는 저입 열 및 고입열 용접부의 경도는 그림 4에서 보는 바와 같이 경 도값이 wire-1의 경우와는 다르게 모재에서 용접부까지 큰 감소 없이 일정하게 유지되는 것을 알 수 있다.

\section{3 용접부 인장 강도}

표 4와 그림 5는 인장시험 결과를 보여주고 있다. Wire-1 의 경우 인장강도는 second pass의 저입열 (A) 조건에서 평균 $300 \mathrm{MPa}$ 이었으며, 연신율은 $16 \%$ 를 나타냈다. 중입열 (B) 조 건에서 인장강도는 $302 \mathrm{MPa}$, 연신율 $18 \%$ 이었으며, 고입열 (C) 조건에서 인장강도 $284 \mathrm{MPa}$, 연신율 $15 \%$ 를 나타냈다. Wire-1의 경우 저입열과 중입열에서 인장강도는 유사하였지 만, 고입열에 경우 인장강도가 하락하였다. 인장시험 중 파단
위치를 확인해 본 결과 3 가지 입열조건 모두 용착금속부에서 파단이 발생하였다(그림5(b)). Wire-2의 경우에는 저입열 (A) 조건에서 인장강도 $302 \mathrm{MPa}$, 연신율 $20 \%$, 중입열 (B) 조 건에서는 인장강도 $301 \mathrm{MPa}$, 연신율 $18 \%$, 고입열 (C) 조건 에서는 인장강도 $302 \mathrm{MPa}$, 연신율 $14 \%$ 의 값을 보였다. 그림 6 은 2 가지 용접와이어를 사용한 용접부의 인장강도를 비교 한 결과이다. 2 가지 용접와이어 모두 저입열, 중입열 조건에 서의 용접부 인장강도는 유사하였다. 그러나 고입열 조건에 서 wire -1 의 용접부 인장강도는 저입열과 중입열 조건 대비 하락하였지만, wire-2의 경우에는 저입열, 중입열, 고입열 조 건에서 유사한 용접부 강도를 나타내고 있다. 이러한 원인은 wire-1에 비해 wire-2의 $\mathrm{Mg}$ 함량이 많아 $\mathrm{Mg}$ 의 고용강화 효 과가 증가하여 고입열 조건에서도 용접부 강도 저하가 발생 하지 않는 것으로 판단된다. Wire-2의 경우에도 wire-1과 마 
Table 5. Effect of heat input condition on $\mathrm{Mg}$ concentration in the weld

\begin{tabular}{|c|c|c|c|c|c|c|c|}
\hline & $\begin{array}{l}\text { heat } \\
\text { input }\end{array}$ & area & $\mathrm{Mg}(\mathrm{wt} \%)$ & & $\begin{array}{l}\text { heat } \\
\text { input }\end{array}$ & area & $\mathrm{Mg}(\mathrm{wt} \%)$ \\
\hline \multirow{12}{*}{ wire-1 } & \multirow{6}{*}{ A } & (1) & 4.53 & \multirow{12}{*}{ wire-2 } & \multirow{6}{*}{ A } & (1) & 5.71 \\
\hline & & (2) & 5.45 & & & (2) & 5.67 \\
\hline & & (3) & 5.28 & & & (3) & 5.73 \\
\hline & & (4) & 5.19 & & & (4) & 5.86 \\
\hline & & (5) & 4.69 & & & (5) & 5.5 \\
\hline & & (6) & 5.05 & & & (6) & 5.72 \\
\hline & \multirow{6}{*}{$\mathrm{C}$} & (1) & 4.55 & & \multirow{6}{*}{$\mathrm{C}$} & (1) & 5.83 \\
\hline & & (2) & 5.21 & & & (2) & 5.63 \\
\hline & & (3) & 5.22 & & & (3) & 5.48 \\
\hline & & (4) & 5.26 & & & (4) & 5.2 \\
\hline & & (5) & 4.59 & & & (5) & 5.12 \\
\hline & & (6) & 4.62 & & & (6) & 5.32 \\
\hline
\end{tabular}

찬가지로 인장시험 시 파단위치는 모든 용접조건에서 용착 금속부에서 발생하였다. wire-2의 경우 앞에서 말했듯이 용 접부 경도와 모재의 경도가 큰 차이가 없었다. 그럼에도 불구 하고 인장 시험 시 용착금속부에서 파단이 발생하는 이유는 모재의 경우 압연 방향으로 미세조직이 발달되어 있어, 인장 시험 시 조직의 방향성이 인장방향과 수평이기 때문에 균열 의 전파가 어렵다. 이에 비해 용접부 중심 조직은 등축 수지 상 조직이기 때문에 인장방향에 따른 균열의 전파가 모재에 비해 용이하다. 따라서 용접부에서 경도값이 모재와 유사한 값을 보임에도 불구하고 용착금속부 중심에서 파단이 발생 하는 것으로 판단된다.

\section{4 용접부 미세조직 및 화학성분}

그림 7과 8 는 와이어 종류별 양면용접 시 second pass의 입 열조건에 따른 용접부 미세조직을 나타내고 있다. 그림에서 보는 바와 같이 모재(1)영역)를 제외한 열영향부 및 용접부 미세조직은 수지상 형태를 나타내고 있다(2)-(6)영역). 용융 부 중심(4)-(6)영역)에서 수지상의 형태가 더욱 뚜렷하게 나 타나고 있으며 first pass와 second pass 용융부(4), (6)영역), 그리고 first pass와 second pass가 겹쳐져서 나타나는 용접부 중심(5)영역)의 미세조직이 입열량에 따라서 수지상의 형태 가 약간씩 다르게 나타난다. 이는 용접부 중심에 있을수록 냉 각속도가 감소하게 되고 이로 인해서 미세조직의 2 차 수지상 간격 (secondary dendrite arm spacing, SDAS)이 점점 커지기 때문이다. 따라서 (2), (3)영역의 SDAS보다는 (4), (5), (6) 영역 의 SDAS가 더 큰 것을 그림을 통해 확인할 수 있다. (4), (5), (6) 영역 중에서는 first pass와 second pass가 겹쳐지는 (5)영

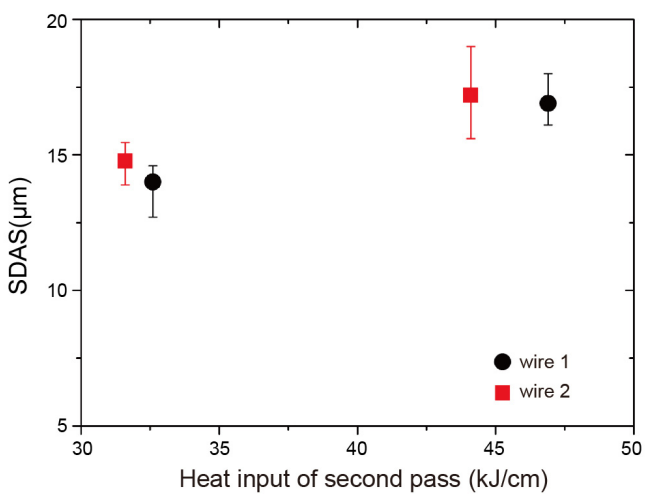

Fig. 9. Effect of heat input of second pass and $\mathrm{Mg}$ content on SDAS in fusion zone

역의 입열량이 가장 많아 SDAS가 가장 크게 성장하게 된다. 이는 용접와이어 종류 및 second pass의 저입열, 고입열 여부 와 상관없이 모두 동일하게 나타나는 현상이다. 그림 9는 wire-1 과 2의 (6) 영역에서의 SDAS를 측정한 결과이다. 그림 에서 보듯이 저입열(A)의 조건에서는 wire-1과 wire-2의 $\mathrm{SDAS}$ 는 $14 \mu \mathrm{m}$ 와 $14.8 \mu \mathrm{m}$ 이며, 고입열(c) 조건에서는 각각 $16.9 \mu \mathrm{m}$ 와 $17.2 \mu \mathrm{m}$ 으로 오차범위 내에서 $\mathrm{Mg}$ 함량에 상관 없이 유사한 값을 보여주고 있다.

표 5는 용접와이어별 용접부 각 위치에서의 $\mathrm{Mg}$ 함량을 측 정한 결과이다. wire- 1 의 경우 second pass 저입열(A)조건의 경우 fusion line 가까이에 있는 (1)영역에서 $4.53 \mathrm{wt} \%$ 로 가장 낮게 나왔다. 그리고 용접부 내부의 $\mathrm{Mg}$ 함량중에서는 first pass 와 second pass의 용접이 겹쳐진 부분인 (5)영역에서 $4.69 \mathrm{wt} \%$ 로 가장 낮게 나타났다. 또한 용접부 내에서는 용접 부 중심으로 갈수록 $\mathrm{Mg}$ 함량이 감소하는 경향을 보였다. 고 입열(C) 조건에서는 저입열 조건과 유사하게 (5)영역에서 $\mathrm{Mg}$ 의 함량이 $4.59 \mathrm{wt} \%$ 이었으며, 저입열의 경우에 마찬가지 로 용접부 중심으로 갈수록 $\mathrm{Mg}$ 함량이 감소하였다.

wire-2의 경우 저입열(A) 조건에서는 용접부에서 가장 낮 은 $\mathrm{Mg}$ 함량은 wire-1과 마찬가지로 (5)영역에서 $5.5 \mathrm{wt} \%$ 였 다. 반면 고입열(C)조건에서도 (5)영역에서 가장 낮은 5.12 $\mathrm{wt} \%$ 의 $\mathrm{Mg}$ 함량을 나타냈다. wire-2의 경우 저입열(A)조건 에서는 $\mathrm{Mg}$ 함량이 용접부 중심과 모재와 가까운 용접부의 차이가 거의 나지 않았으며, 고입열의 경우 저입열조건에 비 해 용접부 중심으로 갈수록 $\mathrm{Mg}$ 함량이 감소하는 경향을 보 였다. 이러한 현상은 wire-1의 경우에서도 나타났으며 이는 고입열 조건에서는 저입열 조건보다 고전류에 따른 아크 입 열로 인한 $\mathrm{Mg}$ 의 기화가 더 많이 발생하기 때문인 것으로 판 
단된다.

앞에서 용접부 인장강도의 경우 $\mathrm{Mg}$ 함량이 높은 wire-2가 wire-1와 비교했을 때 저입열, 중입열 조건에서는 유사했으 나, 고입열 조건에서 더 높은 값을 나타냈었다. 일반적으로 $\mathrm{SDAS}$ 가 작으면 강도가 증가한다고 알려져 있는데 본 연구 에서는 wire-1와 wire-2의 경우 저입열 및 고입열 조건에서 오차범위 내에서 유사한 값을 나타내고 있다. 따라서 고입열 조건에서 wire-1과 wire-2의 인장강도의 차이는 SDAS와의 상관관계 보다는 $\mathrm{Mg}$ 함량의 차이에 따른 고용강화 효과의 차이에 의해서 발생하는 것으로 판단된다.

\section{4. 결 론}

본 연구를 통해 $\mathrm{Mg}$ 함량이 다른 2가지 용접와이어를 이용 하여 알루미늄 5083 합금 용접부의 기계적 특성을 조사하였 으며, 자세한 결론은 다음과 같다.

1) $\mathrm{Mg}$ 함량이 $5.1 \mathrm{wt} \%$ 인 wire- 1 의 경우 양면 맞대기 용접 부에 대한 경도 측정 결과는 저입열 및 고입열 조건에서 용접 부 중심으로 갈수록 경도가 하락하는 경향을 나타내었으나, $\mathrm{Mg}$ 함량이 $5.9 \mathrm{wt} \%$ 인 wire-2의 경우에는 저입열 및 고입열 조건에서 모두 용착금속부에서 경도 감소는 거의 없었다.

2) $\mathrm{Mg}$ 함량이 $5.1 \mathrm{wt} \%$ 인 wire-1의 경우 용접부 인장강도 결과 second pass의 저/중입열 조건에서 약 $300 \mathrm{MPa}$ 로 유사 하였으며, 고입열 조건에서 $284 \mathrm{MPa}$ 로 인장강도가 감소하였 다. 이에 반해 $\mathrm{Mg}$ 함량이 $5.9 \mathrm{wt} \%$ 인 wire-2의 경우 입열에 상 관없이 약 $300 \mathrm{MPa}$ 정도의 인장강도 값을 나타냈다.

3) $\mathrm{Mg}$ 함량이 $5.1 \mathrm{wt} \%, 5.9 \mathrm{wt} \%$ 2가지 경우 모두 용접부 중심에서 수지상의 미세조직이 관찰되었으며 입열량이 증가 함에 따라 $\mathrm{SDAS}$ 가 증가하는 것을 확인하였다. 또한 $\mathrm{Mg}$ 함 량에 따른 SDAS 값은 2가지 와이어의 경우 유사한 값을 나 타내어서 $\mathrm{SDAS}$ 와 인장강도와의 상관관계를 찾기 어려웠다.
4) $\mathrm{Mg}$ 함량이 $5.1 \mathrm{wt} \%$ 인 wire- 1 의 경우 고입열 조건에서 용접부 중심으로 이동할수록 $\mathrm{Mg}$ 함유량이 감소하였으나, $\mathrm{Mg}$ 함량이 $5.9 \mathrm{wt} \%$ 인 wire-2의 경우 모재와 용접부 내 $\mathrm{Mg}$ 함량의 차이가 큰 차이가 없음을 확인하였다. 따라서 고입열 조건에서 $\mathrm{Mg}$ 의 기화가 많이 발생하지 않았기 때문에, $\mathrm{Mg}$ 에 의한 고용강화 효과로 인해 wire-2를 이용한 용접부의 경우 용접부 중심에서 경도 및 강도의 감소가 일어나지 않은 것으 로 판단된다.

\section{REFERENCES}

1. ExxonMobil, The Outlook for Energy: A View to 2040 (2014)

2. U.S. Energy Information Administration, International Energy Outlook 2013, DOE / EIA - 0484 (2013).

3. H. Sung, D. Jeong, T. Park, J. Lee, and S. Kim, Met. Mater. Int. 22, 755 (2016).

4. H.-K. Lee, T.-J. Yoon, and C.-Y. Kang, Koren. J. Met. Mater. 54, 79 (2016).

5. Y. B. Choi, M. J. Kang, D. C. Kim, and I. S. Hwang, J. Korean Weld. Join. Soc. 31, 21 (2015).

6. T. C. Lee, H. W. Lee, D. W. Joo, H. H. Lee, and J. H. Sung, J. Korean Soc. Heat. Treat. 13, 1 (2000).

7. S. H. Hong, J. Korean Weld. Soc. 13, 1 (1995).

8. D.-Y. Ryoo, K.-Y. Kim, Y.-D. Lee, and J.-Y. Kang, J. Kor. Inst. Met. Mater. 39, 1233 (2001).

9. H. Kwon, C.-H. Park, I.-P. Hong, and N. Kang, J. Korean Weld. Join. Soc. 31, 84, (2013).

10. J. L. Searles, P. I. Gouma, and R. G. Buchheit, Metall. Mater. Trans., 32A, 2859 (2001).

11. J. H. Han, K. K. Jee, and K. H. Oh, J. Kor. Inst. Met. \& Mater. 42, 530 (2004).

12. A. Blake and J. Mazumder, Trans. ASME 107, 276 (1985)

13. H. Zhao and T. Debroy, Metall. Mater. Trans. 32B, 163 (2001).

14. T. Mukai, K. Higashi, and S. Tanimura, Mater. Sci. Eng. 176, 181 (1994).

15. J. B. Wang, H. Nishimura, S. Katayama, and M. Mizutani, Trans. Jpn. Weld. Res. Inst. 39, 19 (2010). 